\title{
Performance and Stability of Some Durum Wheat Genotypes under Different Sowing Dates and Nitrogen Fertilizer Levels
}

\author{
A.G. Abd El-Rady and Y.S.I. Koubisy \\ Wheat Res. Dept., Field Crops Res. Inst., ARC, Giza, Egypt.
}

\begin{abstract}
The present study was carried out at Shandaweel Agricultural Research Station, Agricultural Research Center, Egypt. Eight durum wheat genotypes of diverse origin were evaluated under 12 environments, which are a combination between three sowing dates, i.e., $20^{\text {th }}$ November, $10^{\text {th }}$ December and $30^{\text {th }}$ December under two levels of nitrogen fertilizer, i.e., 50 and $75 \mathrm{~kg} \mathrm{~N} /$ fed during two winter growing seasons of 2015/2016 and 2016/2017. The combined analysis of variance revealed high significant differences among environments, genotypes as well as genotype $\times$ environment interaction for six studied traits i.e., days to $50 \%$ heading, plant height, number of spikes $/ \mathrm{m}^{2}$, number of kernels/spike, 1000-kernel weight and grain yield/fed. The results showed that sowing at the favorable date $\left(20^{\text {th }}\right.$ November $)$ using $75 \mathrm{~kg} / \mathrm{fed}$ nitrogen fertilizer increased all studied traits. The joint regression analysis of variance for the studied traits showed high significant mean squares due to environment + genotype $\times$ environment interactions revealing that genotypes considerably interacted with the environmental conditions. The mean squares due to $\mathrm{G} \times \mathrm{E}$ (linear) were found to be significant for all studied traits, except for days to heading and 1000-kernel weight which reveals genetic variability among genotypes for linear response to varying environments. Stability parameters (bi and $S^{2} d$ ) revealed that six genotypes were stable for days to heading, six for plant height, three for number of spikes $/ \mathrm{m}^{2}$, three for number of kernels/spike and six for 1000-kernel weight. Five out of the eight studied genotypes, i.e., Sohag 5, line 2, line 3, line 4 and line 5 showed non-significant deviation from regression and their regression coefficient values were close to unity which are classified as stable genotypes for grain yield. Two genotypes had grain yield higher than the grand mean (Sohage 5 and Line 4) and could be considered the most adapted genotypes.
\end{abstract}

Key words: Triticum turgidum, Stability parameters, Grain yield, Genotypes.

\section{INTRODUCTION}

Wheat crop is considered one of the essential strategic cereal crops not only in Egypt but also all over the world since it is a staple food for humans. Due to limited arable area and irrigation supply, an increase of productivity per unit land area appears to be the mainly possible alternate of reducing the wheat production gap. This can be achieved by introducing high yielding cultivars and simultaneously implementing improved cultural practices. Such improved cultivars must tolerate the unfavorable environments and be stable in broad spectrum of environments. Sowing date is an important factor that affects phenophases and grain yield and its components of wheat (Kiss et al., 2013). The use of different sowing dates allow us to expose wheat cultivars to different atmospheric temperatures, which is considered the major environmental factor drastically reducing wheat production. Nitrogen plays an important role in plant life and it is considered an indispensable element for several vital functions. Several investigators reported that increasing nitrogen level more than $50 \mathrm{~kg} / \mathrm{fed}$. Is accompanied by a significant increase in plant height, number of spikes $/ \mathrm{m}^{2}$, spike length, number of spikelets/spike, number of grains and weight/spike, 1000-grain weight and grain yield (Ahmed et al., 2009; Ansar et al., 2010; Abd EL-Hameed, 2012; Kouzegaran et al., 2015 and Fadle et al. 2016). Hence, identification of genotypes with a high potential for yield and stability across environments is an essential task in plant breeding. The adaptability of a variety over diverse environments is usually tested by the degree of its interaction with different environments under, which it is grown. The phenotypic performance of a genotype is not necessarily the same under divers agro-ecological conditions (Ali et al., 2003). Some genotypes may perform well in certain environments, but fail in others. This variation is due to $\mathrm{G} \times \mathrm{E}$ interaction, which reduces the stability of a genotype under different environments (Ashraf et al., 2001). Therefore, the adaptability and stability are analyzed to allow the identification of the genotypes with predictable behavior that may respond to the prevailing environmental variations under specific or general conditions (Silva et al., 2014). The adaptability is evaluated based on the average performance of the genotypes. Meanwhile, stability is defined as the ability of the genotype to exhibit a yield that is a constant as possible, depending on variation in the quality of the environment. A 
genotype is considered stable if its performances are relatively constant across environments. Many models have been developed to measure stability of various parameters and partitioning of variation due to $\mathrm{G} \times \mathrm{E}$ interactions. The most widely used model (Eberhart \& Russell, 1966) was followed to interpret stability statistics in different crops. Several studies reported significant differences among wheat genotypes in their response to the environmental conditions and hence, their grain yields (Ismail, 1995; Amin, 2006; Tawfiles, 2006; Hamam and Abdel-Sabour, 2009; El Ameen 2012; Abd El-Shafi et al. 2014 and Haddad et al. 2016). The objectives of this study were: 1) to evaluate grain yield and its components of eight durum wheat genotypes at three sowing dates and two levels of nitrogen fertilizer, 2) to estimate stability parameters of the eight durum wheat genotypes under 12 environments (two year, three sowing dates and two levels of nitrogen fertilizer) to select the most adapted durum wheat genotypes.

\section{MATERIALS AND METHODS}

This study was carried out in 2015/2016 and 2016/2017 seasons at the Experimental Farm of Shandaweel Agricultural Research Station, Agricultural Research Center (ARC), Egypt. Eight durum wheat genotypes included three cultivars and five advanced lines (Table 1) were evaluated in 12 environments as follow: 2 years, 3 sowing dates and 2 nitrogen fertilizer levels (Table 2). The experimental design was a split-split plot arrangement of treatment with three replicates in a randomized complete block design. The three sowing dates $\left(20^{\text {th }}\right.$ Nov., $10^{\text {th }}$ Dec. and $30^{\text {th }}$ Dec.) were assigned to the main plots. The two nitrogen fertilizer levels (50 and $75 \mathrm{~kg} / \mathrm{fed}$ ) were assigned to the sub-plots, while the sub-sub-plots were devoted to the eight wheat genotypes. The plot size was 8.4 $\mathrm{m}^{2}$, seeds were drilled sown in 12 rows, $20 \mathrm{~cm}$ apart. The recommended agricultural practices of wheat production were adopted in both growing seasons. Data were recorded on days to $50 \%$ heading, plant height $(\mathrm{cm})$, number of spikes $/ \mathrm{m}^{2}$, number of kernels/spike, 1000-kernel weight (g) and grain yield ( $\mathrm{ard} / \mathrm{fed})$.

\section{Statistical analyses}

Analysis of variance was carried out for each environment separately. Test of homogeneity (Bartlett, 1937) of the error mean squares across all environments was performed. Hence, the combined analysis was performed in this study according to Gomez and Gomez (1984). Least significant difference (LSD) was used for comparing means. Stability analysis for studied traits across all environments was performed according to Eberhart and Russell (1966). Three criteria would be realized to consider a genotype as stable one, these criteria as are follows:

1- Regression coefficient significantly different from zero $(b \neq 0)$ and not significantly different from unity $(b=1)$.

2- Non-significant sums of squares of the deviation of regression, i.e., $\mathrm{S}^{2} \mathrm{di}=0$.

3- High performance with a reasonable range of environmental variation.

All statistical analysis were carried out using MSTAT-C software package and by GENES computer software (Cruz, 2013).

Table 1: Name, pedigree and origin of the studied wheat genotypes

\begin{tabular}{|c|c|c|c|}
\hline No & Name & Pedigree & Origin \\
\hline 1 & Sohag 4 & $\begin{array}{l}\text { AJAIA-16//HORA/JRO/3/GAN/4/ZAR/5/SUOK } \\
\text { 7/6/STOT//ALTRA84/ALD }\end{array}$ & EGYPT \\
\hline 2 & Sohag 5 & $\begin{array}{l}\text { TRN//21563/AA/3/BD2080/4/BD2339/5/RASCO37//TARRO } \\
\text { 2//RASCON 3/6/AUK/GULL//GREEN }\end{array}$ & EGYPT \\
\hline 3 & Bani Suef 5 & DIPPER-2/BUSHEN-3 & EGYPT \\
\hline 4 & Line \#1 & $\begin{array}{l}\text { DUKEM_1//PATKA_7/YAZI_1/3/PATKA_7/YAZI_1/4/ } \\
\text { TARRO_1/2*YUAN_1//AJAIA_13/YAZI/5/PATKA_4/PLATA_16 }\end{array}$ & CIMMYT \\
\hline 5 & Line \#2 & $\begin{array}{l}\text { LARETAINIA/4/SKEST//HUI/TUB/3/SILVER/5/LHNKE/ } \\
\text { RASCON//CONAD/6/GREEN_32/CHEN_7//SILVER_14/3/DIPPER_ } \\
\text { 2/BUSHEN_3/4/SNITAN }\end{array}$ & CIMMYT \\
\hline 6 & Line \#3 & $\begin{array}{l}\text { PLATA_10/6/MQUE/4/USDA573//QFN/AA_7/3/ALBA- } \\
\text { D/5/AVO/HUI/7/PLATA_13/8/THKNEE_11/9/CHEN/ALTAR84/3/H } \\
\text { UI/POC//BUB/RUFO/4/FNFOOT/10/SOMAT_4/INTER_8 }\end{array}$ & CIMMYT \\
\hline 7 & Line \#4 & $\begin{array}{l}\text { AJAIA_3/SILVER_16//AJAIA_13/YAZI/4/ARMENT// } \\
\text { SRN_3/NIGRIS_4/3/CANELO_9.1/5/GODRIN/GUTROS//DUKEM/ } \\
\text { 3/THKNEE_11 }\end{array}$ & CIMMYT \\
\hline 8 & Line \# 5 & SOHAG 2//SOOTY-9/RASCON 37 & EGYPT \\
\hline
\end{tabular}


Table 2: Characterization of the 12 environments used in this investigation.

\begin{tabular}{|c|c|c|c|c|c|c|c|c|c|c|c|c|}
\hline Env. & E1 & E2 & $\mathbf{E 3}$ & E4 & E5 & E6 & E7 & E8 & E9 & E10 & E11 & E12 \\
\hline Season & \multicolumn{6}{|c|}{$2016 / 2015$} & \multicolumn{6}{|c|}{$2017 / 2016$} \\
\hline Sowing & 20 & 20 & 10 & 10 & 30 & 30 & 20 & 20 & 10 & 10 & 30 & 30 \\
\hline date & Nov. & Nov. & Dec. & Dec. & Dec. & Dec. & Nov. & Nov. & Dec. & Dec. & Dec. & Dec. \\
\hline $\begin{array}{l}\text { Nitrogen } \\
\text { fertilizer }\end{array}$ & $50 \mathrm{~kg}$ & $75 \mathrm{~kg}$ & $50 \mathrm{~kg}$ & $75 \mathrm{~kg}$ & $50 \mathrm{~kg}$ & $75 \mathrm{~kg}$ & $50 \mathrm{~kg}$ & $75 \mathrm{~kg}$ & $50 \mathrm{~kg}$ & $75 \mathrm{~kg}$ & $50 \mathrm{~kg}$ & $75 \mathrm{~kg}$ \\
\hline
\end{tabular}

Table 3: Mean maximum and minimum air temperatures $\left({ }^{\circ} \mathrm{C}\right)$ during 2015/2016 and 2016/2017 growing seasons.

\begin{tabular}{lcccccccc}
\hline Month & & November & December & January & February & March & April & May \\
\hline \multirow{2}{*}{$2015 / 2016$} & Max. & 27 & 21 & 19 & 25 & 28 & 36 & 38 \\
\cline { 2 - 9 } & Min. & 15 & 9 & 7 & 10 & 15 & 19 & 23 \\
\hline \multirow{2}{*}{$2016 / 2017$} & Max. & 28 & 21 & 20 & 21 & 26 & 33 & 38 \\
\cline { 2 - 9 } & Min. & 15 & 8 & 7 & 7 & 12 & 18 & 22 \\
\hline
\end{tabular}

Table 4: Soil chemical analysis at the experimental site during 2015/2016 and 2016/2017 seasons.

\begin{tabular}{|c|c|c|c|c|c|c|c|c|c|}
\hline \multirow{2}{*}{ Season } & \multirow{2}{*}{ pH } & \multirow{2}{*}{ EC dS m $\mathbf{m}^{-1}$} & \multicolumn{4}{|c|}{ Cations Meq $\mathrm{L}^{-1}$} & \multicolumn{3}{|c|}{ Anions Meq $\mathrm{L}^{-1}$} \\
\hline & & & $\mathrm{Ca}^{++}$ & $\mathbf{M g}^{++}$ & $\mathrm{Na}^{+}$ & $\mathbf{K}^{+}$ & $\mathrm{SO}_{4}=$ & $\mathrm{Cl}^{-}$ & $\mathrm{HCO}_{3}^{-}$ \\
\hline 2016 & 7.4 & 0.52 & 0.21 & 0.40 & 4 & 0.21 & 1.22 & 1.0 & 0.21 \\
\hline 2017 & 7.6 & 0.61 & 0.50 & 0.81 & 4.5 & 0.42 & 1.72 & 1.3 & 0.30 \\
\hline
\end{tabular}

Available nutrients ppm

\begin{tabular}{llllllll}
\hline & $\mathbf{N}$ & $\mathbf{P}$ & $\mathbf{K}$ & $\mathbf{Z n}$ & Mn & Fe & $\mathbf{C u}$ \\
\hline 2016 & 52 & 16 & 320 & 0.36 & 1.2 & 1.2 & 0.60 \\
\hline 2017 & 55 & 19 & 290 & 0.47 & 1.5 & 1.0 & 0.62 \\
\hline
\end{tabular}

\section{RESULTS AND DISCUSSION}

1. Environment-Genotypes variations and $\mathbf{G} \times \mathbf{E}$ interactions:

Data for separate traits were statistically analyzed as usual, test of homogeneity of the error mean squares across all environments was done. Error mean squares were not significant for all studied traits, indicating that errors homogeneous, so the combined analysis was followed up in this study. The combined analysis of variance (Table 5) revealed high significant differences among environments and genotypes for all studied traits, indicating the variability in genotypes as well as diversity of growing conditions at different environments. Moreover, the genotype $\times$ environment interaction variance was also significant for all the studied traits. These results indicated that studied genotypes differently responded to the different environmental conditions, suggesting the importance of the assessment of genotypes under different environments in order to identify the best genetic make up for a particular environment. These results are in harmony with those found by Amin (2006), Tawfelis (2006), Akcura et al. (2009), Hamam and Abdel-Sabour (2009), Hassan et al. (2013) and Abd El-Shafi et al. (2014).

2. Mean performance of genotypes:

Environmental means indicate that the highest means for all traits under the study were obtained by sowing at the favorable date of $20^{\text {th }}$ Nov. using 75 $\mathrm{kg} /$ fed nitrogen fertilizer, while the lowest mean values were obtained when wheat genotypes were sown at late date $30^{\text {th }}$ Dec. using $50 \mathrm{~kg} /$ fed nitrogen fertilizer. For days to heading (Table 6) the average of the environments ranged from 73.1 to 98.4 days for E5 and E8, respectively. As for the genotypes the days to heading ranged from 83.1 to 89.6 days for Bani Suef 5 and line 5, respectively; with an overall average of 85.9 days. The earliest genotype was Bani Suef 5 under E5 70.0 days, while the latest genotype was line 5 under E8 103.0 days. Moreover, the results clearly showed that late sowing and decrease nitrogen fertilizer from 75 $\mathrm{kg} /$ fed to $50 \mathrm{~kg} /$ fed decreased days to heading in the two seasons. Hamam and Abdel-Sabour (2009) found that number of days to heading decreased by delaying sowing under low nitrogen fertilizer.

Regarding plant height (Table 6), results showed different performance among environments. Means of plant height across all genotypes ranged from $84.4 \mathrm{~cm}$ at $30^{\text {th }}$ Dec. sowing under $50 \mathrm{~kg} / \mathrm{fed}$ nitrogen fertilizer in 2016 season to $107.2 \mathrm{~cm}$ at $20^{\text {th }}$ Nov. sowing date under $75 \mathrm{~kg} /$ fed nitrogen fertilizer in 2017 season. This indicates that delaying sowing under reduced nitrogen fertilizer rate led to the decreased plant height of genotypes. Increase in plant heights caused by higher nitrogen addition can be attributed to the fact that nitrogen as a main constituent of protein and protoplasm, 
Table 5: Mean squares from the combined of variance for studied traits of the eight durum wheat genotypes tested across different environments

\begin{tabular}{lccccccc}
\hline $\begin{array}{l}\text { Source of } \\
\text { variation }\end{array}$ & d.f & $\begin{array}{c}\text { Days to } \\
\text { heading }\end{array}$ & $\begin{array}{c}\text { Plant } \\
\text { height, cm }\end{array}$ & $\begin{array}{c}\text { No. of } \\
\text { spikes/ m }\end{array}$ & $\begin{array}{c}\text { No. of } \\
\text { kernels/ } \\
\text { spike }\end{array}$ & $\begin{array}{c}\text { 1000- } \\
\text { kernel } \\
\text { weight, g }\end{array}$ & $\begin{array}{c}\text { Grain } \\
\text { yield } \\
\text { (ard/fed) }\end{array}$ \\
\hline Environments & 11 & $1408.0^{* *}$ & $980.06^{* *}$ & $13923.38^{* *}$ & $306.20^{* *}$ & $244.07^{* *}$ & $349.77^{* *}$ \\
\hline Replicates/E & 24 & 2.44 & 29.84 & 119.33 & 6.02 & 3.33 & 1.76 \\
\hline Genotypes (G) & 7 & $125.39^{* *}$ & $1081.50^{* *}$ & $2302.72^{* *}$ & $248.98^{* *}$ & $89.06^{* *}$ & $37.33^{* *}$ \\
\hline G x E & 77 & $4.46^{*}$ & $15.83^{* *}$ & $238.05^{* *}$ & $26.13^{* *}$ & $4.182^{*}$ & $1.94 * *$ \\
\hline Pooled error & 168 & 3.078 & 8.501 & 127.499 & 6.923 & 2.988 & 1.246 \\
\hline$*, * *$ significant at 0.05 and 0.01 levels of probability, respectively & & &
\end{tabular}

stimulated and increased cell division and elongation. Decreasing in plant height with delaying in sowing date and decreasing nitrogen fertilizer rate was also reported by Hameed et al. (2003), Hamam and Abdel-Sabour (2009) and Abdel Nour and Fateh (2011) and Fadle et al. (2016). Furthermore, the results showed that the average of plant height across all environments ranged from $92.3 \mathrm{~cm}$ for Line 1 to $109.3 \mathrm{~cm}$ for Line 5 with an overall average of $96.4 \mathrm{~cm}$.

Concerning number of spikes/ $\mathrm{m}^{2}$ (Table 7 ), the mean of the environments ranged from 335.4 to 407.5 for E5 and E8, respectively. As for the genotypes, Bani Suef 5 gave the lowest number of spikes $/ \mathrm{m}^{2}$, while Sohag 5 gave the highest number of spikes $/ \mathrm{m}^{2}$ across all environments. Furthermore, the results clearly showed that delaying sowing and decreasing nitrogen fertilizer decreased number of spikes $/ \mathrm{m}^{2}$. This might be due to the high efficiency of plants to convert solar energy to chemical energy, which increased number of spikes $/ \mathrm{m}^{2}$ with sowing on $20^{\text {th }}$ Nov. than the other tested sowing dates. These results are in harmony with those obtained by Nasim et al. (2006) and Alisial et al. (2010) who found that the delay in sowing from 30 Nov. to 15 and 30 Dec. significantly reduced number of spikes $/ \mathrm{m}^{2}$. On the other hand, High rates of nitrogen fertilizer applied early can stimulate excessive spike bearing of tillers under favorable conditions. Ansar et al. (2010) and Javaid Iqbal et al. (2012) found that number of spikes $/ \mathrm{m}^{2}$ increased with increasing nitrogen rates.

For mean number of kernels/spike (Table 7), the mean of number of kernels/spike across all genotypes ranged from 45.3 for E5 to 57.8 for E8 in 2017 season. The average of number of kernels/spike across all environments ranged from 48.7 for line 5 to 55.9 for Sohage 4. The lower kernels number/spike in all genotypes was observed at late sowing; it might be due to high temperature during the reproductive phase which can cause pollen sterility and adverse effects on floral organs, consequently, decreased number of grain per spike (Prasad et al., 2008).
Regarding the 1000-kernel weight, means of the 8 wheat genotypes at each environment and across all environments are presented in Table 8 . Results showed that the mean of the environments ranged from $46.9 \mathrm{~g}$ for E11 to $57.4 \mathrm{~g}$ for E8 in season 2017. The average of 1000-kernel weight across all environments ranged for $50.2 \mathrm{~g}$ for line 3 to $54.6 \mathrm{~g}$ for line 4 with an overall average of $52.2 \mathrm{~g}$. Results cleared that 1000-kernel weight was decreased proportionally as the planting was delayed. This may be due to high temperatures at delayed sowing affecting the grain maturity that resulted in shrinked grains. These results are in agreement with those by Menshawy (2007); Hamam and Abdel-Sabour (2009); Abdel Nour and Fetah (2011); Gheith et al. (2013) and Fadle et al.(2016). Increase of 1000kernel weight with optimum nitrogen rate may be due to higher grain protein (Guenis et al., 2003).

Mean of grain yield ( $\mathrm{ard} / \mathrm{fed}$ ) for the eight genotypes across 12 environments and across all environments are presented in Table 8 . The results showed different performance of grain yield among environments. The mean grain yield across all genotypes varied from $13.85 \mathrm{ard} / \mathrm{fed}$ at $30^{\text {th }} \mathrm{Dec}$. sowing date under $50 \mathrm{~kg} / \mathrm{fed}$ nitrogen fertilizer in 2016 season to $25.78 \mathrm{ard} / \mathrm{fed}$ at $20^{\text {th }}$ Nov. sowing date under $75 \mathrm{~kg} / \mathrm{fed} \mathrm{nitrogen} \mathrm{fertilizer} \mathrm{in} 2017$ season. The average of grain yield for genotypes across all environments ranged from $18.39 \mathrm{ard} / \mathrm{fed}$ for Line 2 to $21.33 \mathrm{ard} / \mathrm{fed}$ for Sohag 5. These results indicated that delayed sowing decreased grain yield this may be due to the high temperature during delay sowing, which prolonged the period of grain filling and resulted in reduce development of grain and ultimately decreasing the grain yield (Guilioni et al., 2003). The highest grain yield of wheat crop with maximum level of nitrogen fertilizer could be attributed to availability of plant nutrients in abundant amount resulting in more fertile tillers, heavy 1000-kernel weight and more grains / spike, which ultimately led to a maximum grain yield. These results are confirmed by Hameed et al. (2003) and Tammam and Tawfelis (2004), who concluded that grain yield increased with increasing fertilizer rate. 


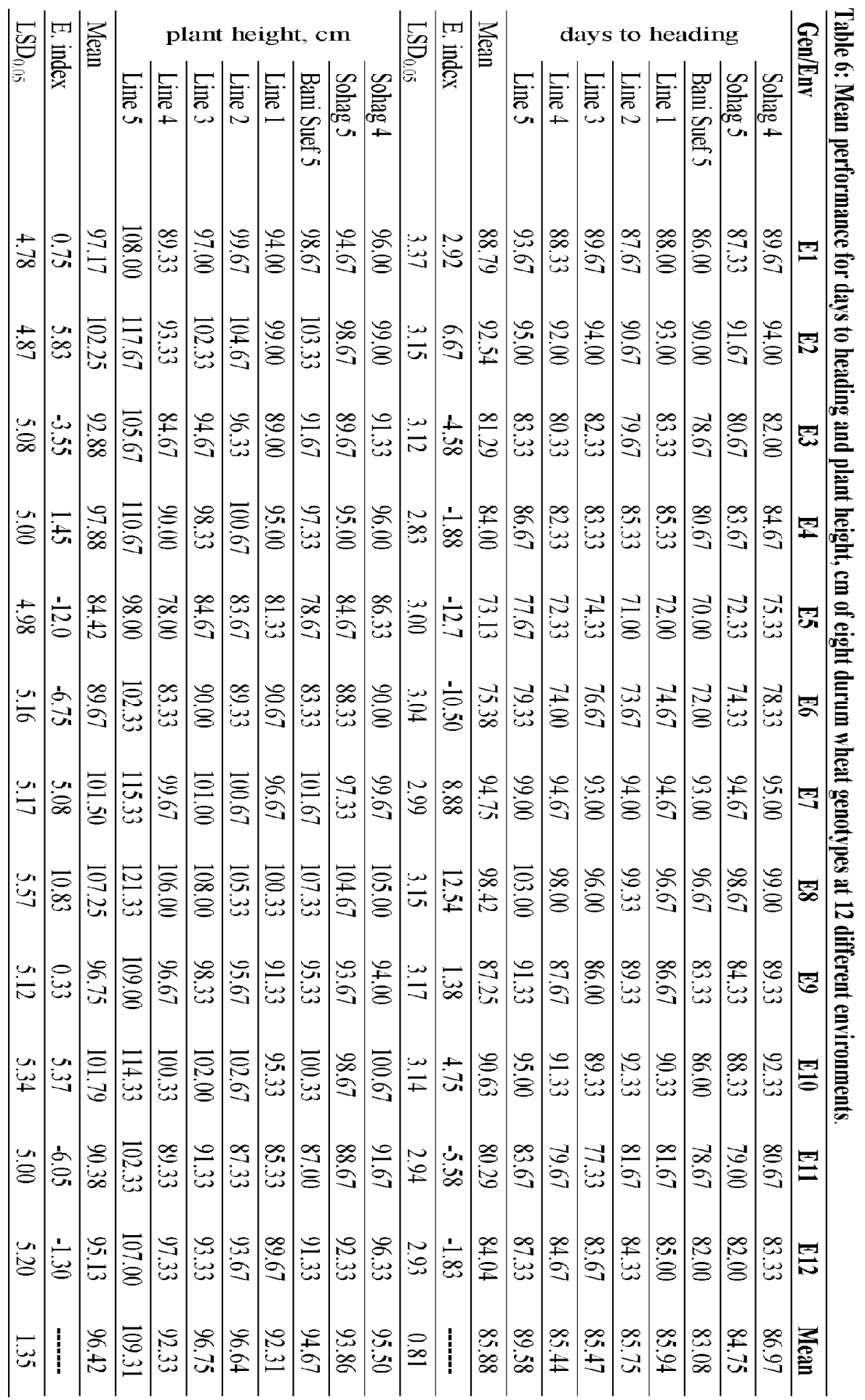




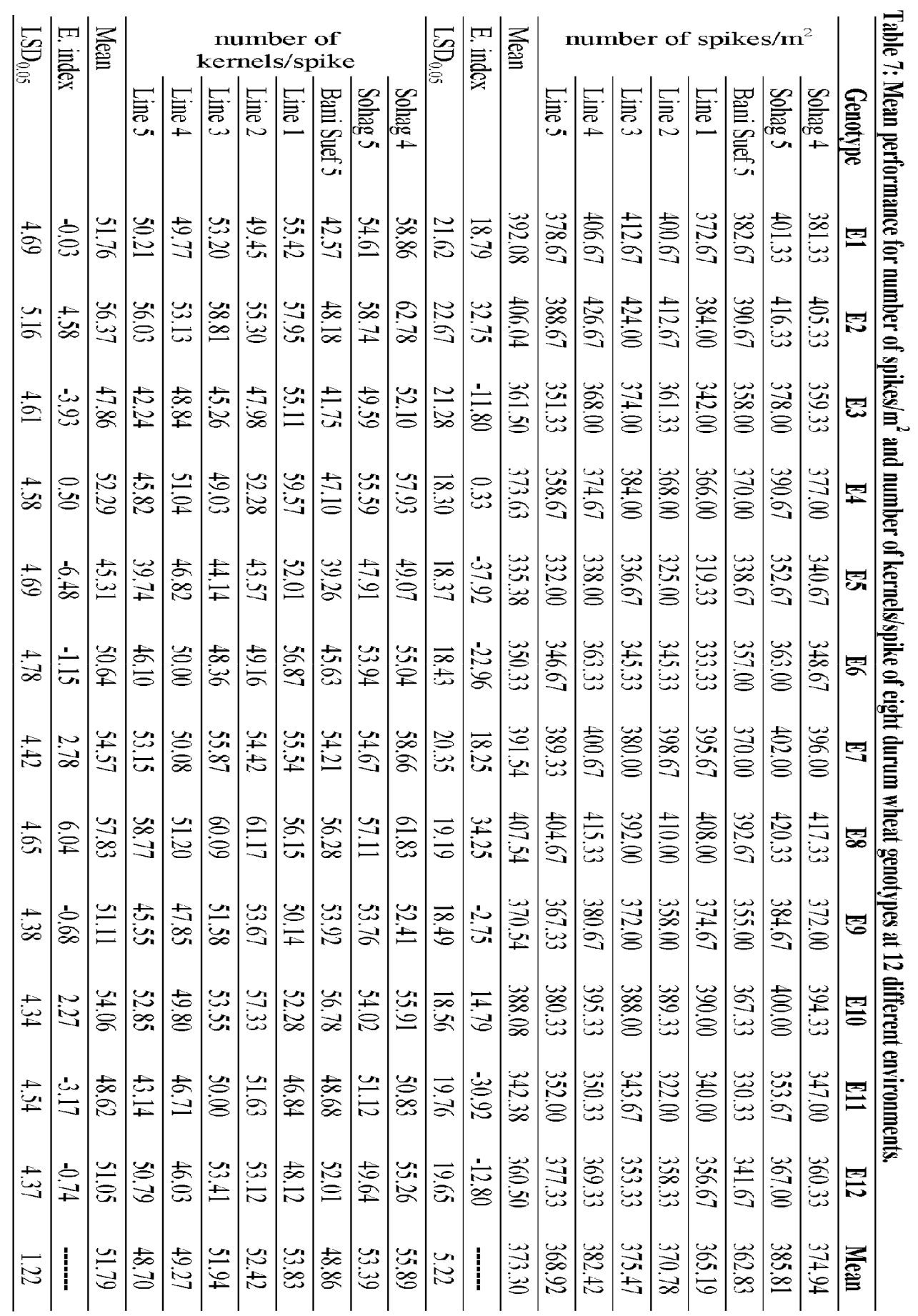




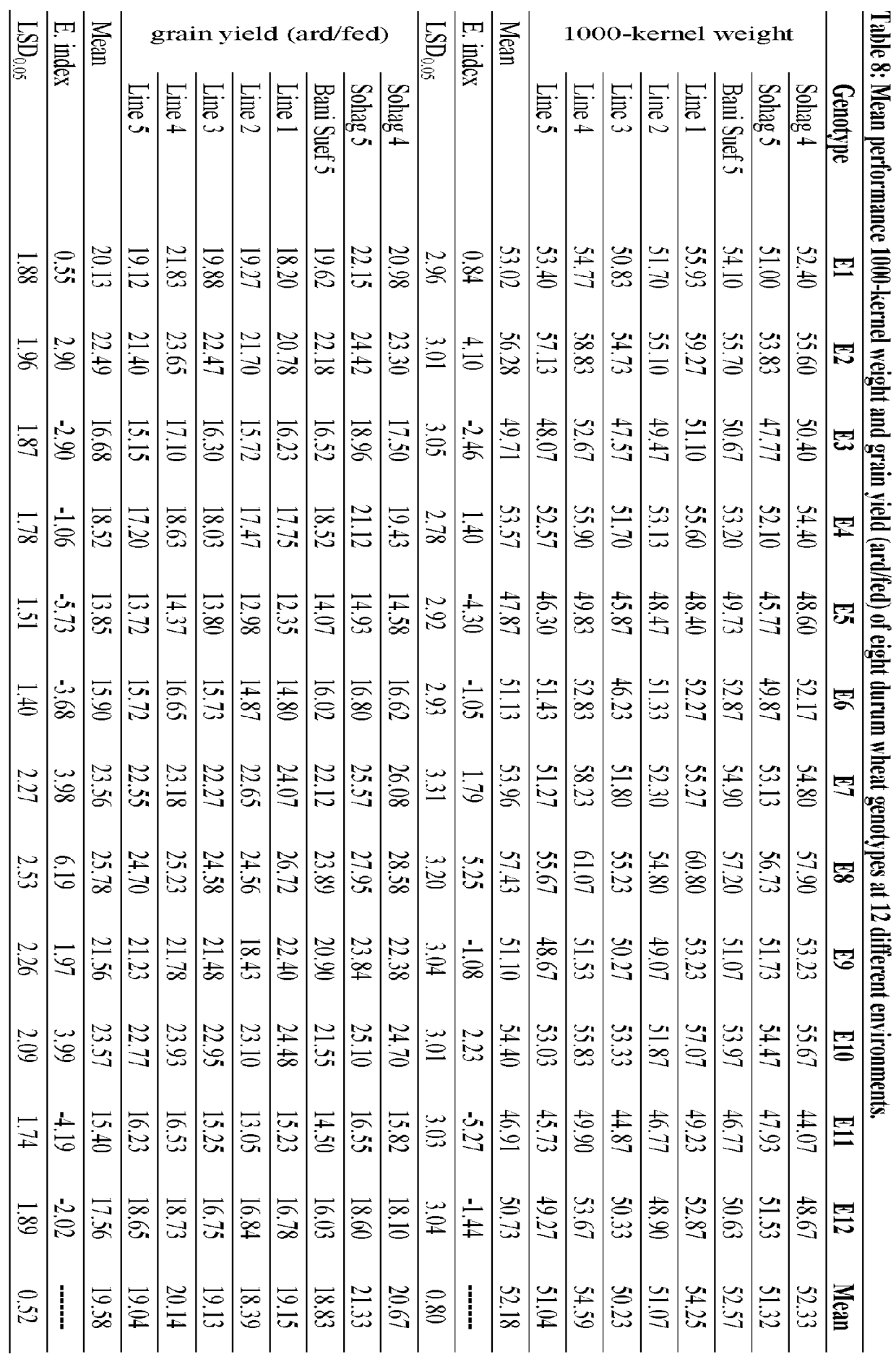




\section{Joint regression analysis:}

The joint regression analysis of variance for the studied traits is presented in Table 9. The variances among genotypes, environments and genotypes $\times$ environments interaction were highly significant for all the studied traits, indicating the presence of wide variability among the genotypes as well as environments and reflecting the differential response of genotypes in various environments. Furthermore, all mean squares of Env. $+(\mathrm{G} \times$ Env. $)$ interaction indicates that the genotypes considerably interacted with the twelve environmental conditions. In fact, Env. $+(G \times$ Env. $)$ ss interaction for each trait is only a makeup of the two parts; Env. and $G \times$ Env ss of the same trait. Env. ss is completely represented by Env. (linear) in which its mean square was highly significant for the studied traits, indicating differences among environments and their influences would remarkably be reflected on the studied traits. Also, the partition of $\mathrm{G} \times$ Env ss interaction of the studied traits into its two components; i.e., regression ss $\mathrm{G} \times$ Env (Iinear) ss and deviations from regression pooled deviations, demonstrated that GxE (linear) ss was significant for all studied traits, except for days to heading and 1000-kernel weight, indicating the presence of genetic differences among genotypes for their regression on the environmental index. Therefore, it could be proceeded in the stability analysis Eberhart and Russell (1966). The significance of pooled deviation mean squares for all studied traits except, days to heading, 1000-kernel weight and grain yield suggests that performance of different genotypes were significantly fluctuated from their respective linear path of response to environments. These findings are in agreement with those obtained by Kheiralla et al. (2004), Amin (2006), Hamam and Abdel-Sabour (2009), Parveen et al. (2010), Hassan et al. (2013) and Mohamed and Said (2014).

\section{Stability parameters:}

It is important to report that plant breeders in executing selection programs would prefer to select genotypes with high average performance and most stable across various environments. For each genotype, the values of mean performance over environments $\overline{(\mathrm{X})}$, the stability regression coefficient (bi) and deviation from regression $\left(\mathrm{S}^{2} \mathrm{di}\right)$ for each genotype and for all studied traits are presented in Table 10. According to the definition of Eberhart and Russell (1966), a stable genotype is one with a high mean performance, unit regression coefficient $(\mathrm{bi}=1)$ and deviation from regression equal to zero $\left(S^{2} \mathrm{di}=0\right)$.

\section{Days to heading:}

Data in Table 10 indicated that six genotypes were stable due to their bi's and $S^{2}$ di's did not differ significantly from a unit and the zero, respectively. The genotypes Sohag 4 and line 1 are considered specifically adapted to the unfavorable environments because the regression coefficients were less than 1 (bi<1), while sohag 5, Bani Suef 5, line 4 and line 5 were adapted to favorable environment (bi>1). Line 2 and 3 were considered as genotypes with poor stability. This significant deviation from regression for heading date was attributed by Joppa et al. (1971). These results are in harmony with those obtained by Kheiralla and Ismail (1995), El-Morshidy et al. (2000), Amin (2006), Hamam and Abdel-Sabour (2009) and Mohamed and Said (2014).

Plant height (cm):

Six out of the eight studied genotypes i.e., Sohag 4, Sohag 5, line 1, line 2, line 3 and line 5 were stable and gave bi and $\mathrm{S}^{2} \mathrm{di}$ did not differ significantly from a unit and the zero, respectively. While the other genotypes were unstable because bi was significant from unity for Bani Suef 5 and $S^{2} d$ was significant from zero for line 4.

Number of spikes $/ \mathbf{m}^{2}$ :

Results in Table 10 indicated that Sohag 4, Sohag 5 and line 4 genotypes were stable and gave bi and $S^{2}$ di did not differ significantly from a unit and the zero, respectively. The other genotypes were unstable (bi was significant from unity and/or $\mathrm{S}^{2} \mathrm{~d}$ was significant from zero). Sohag 5 is considered adapted to unfavorable environment $(\mathrm{bi}<1)$, while line 4 is considered adapted to favorable environment ( $\mathrm{bi}>1)$. The most desired and stable genotypes can be considered when their regression coefficient equal one $(\mathrm{bi}=1)$ with lower values of $\mathrm{S}^{2} \mathrm{di}$ (Eberhart and Russell, 1966), accordingly in this study Sohag 4 was considered as desired and stable for number of spikes $/ \mathrm{m}^{2}$ when compared with grand mean. These findings are in agreement with those obtained by EI-Morshidy et al. (2000) Amin (2006) and Mohamed and Said (2014).

\section{Number of kernels/spike:}

Three genotypes; Sohag 4, Sohag 5 and line 3 (Table 10) have high average comparing to the grand mean and insignificant bi and $\mathrm{S}^{2} \mathrm{~d}$ from unity and the zero. The other genotypes were unstable because bi was significant from unity and/or $\mathrm{S}^{2} \mathrm{~d}$ was significant from zero. The Sohag 4 and line 3 were stable and performed better in favorable environments (bi $>1$ ), while Sohag 5 was stable and performed better in unfavorable environment $(\mathrm{bi}<1)$. Our results are in line with those obtained by ElMorshidy et al. (2000), Amin (2006) and Mohamed and Said (2014).

\section{0-kernels weight (g):}

Regarding the 1000-kernel weight, results in Table 10 revealed that all studied genotypes except, Sohag 4 and line 2 exhibited insignificant stability parameters from unity and from zero for the regression coefficient (bi) and deviation from regression $\left(\mathrm{S}^{2} \mathrm{~d}\right)$, respectively. 


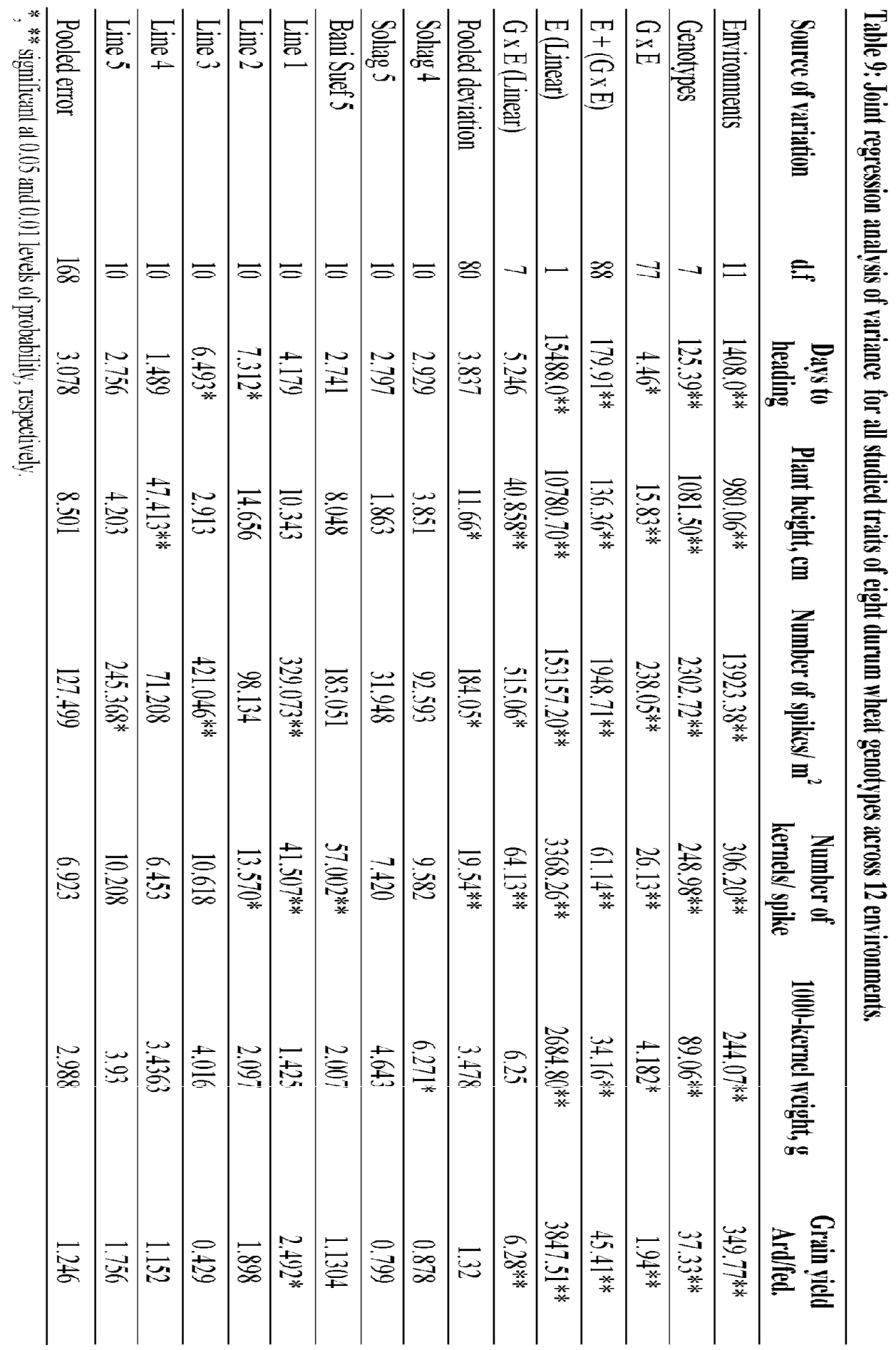


Table 10: Stability parameters for studied traits of eight durum wheat genotypes under 12 environments

\begin{tabular}{|c|c|c|c|c|c|c|c|c|c|}
\hline \multirow[b]{2}{*}{ Genotype } & \multicolumn{3}{|c|}{ days to heading } & \multicolumn{3}{|c|}{ plant height, $\mathrm{cm}$} & \multicolumn{3}{|c|}{ number of spikes $/ \mathrm{m}^{2}$} \\
\hline & Mean & bi & $S^{2}$ di & Mean & bi & $S^{2}$ di & Mean & bi & $S^{2}$ di \\
\hline Sohag 4 & 86.97 & 0.95 & -0.049 & 95.50 & 0.79 & -1.55 & 374.94 & 1.00 & -11.63 \\
\hline Sohag 5 & 84.75 & 1.02 & -0.093 & 93.86 & 0.86 & -221 & 385.81 & 0.95 & -31.85 \\
\hline Bani Suef 5 & 83.08 & 1.03 & -0.112 & 94.67 & $1.31 * *$ & -0.154 & 362.83 & $0.76^{*}$ & 18.52 \\
\hline Line1 & 85.94 & 0.96 & 0.366 & 92.31 & 0.822 & 0.611 & 365.19 & 1.05 & $67.19 * *$ \\
\hline Line2 & 85.75 & 1.06 & $1.411^{*}$ & 96.64 & 1.04 & 2.04 & 370.78 & $1.28 * *$ & -9.78 \\
\hline Line3 & 85.47 & 0.91 & $1.136^{*}$ & 96.75 & 0.984 & -1.86 & 375.47 & 1.03 & $97.84 * *$ \\
\hline Line4 & 85.44 & 1.04 & -0.529 & 92.33 & 1.11 & $12.96^{* *}$ & 382.42 & 1.09 & -18.76 \\
\hline Line5 & 89.58 & 1.02 & -0.107 & 109.31 & 1.06 & -1.43 & 368.92 & 0.80 & $39.28 *$ \\
\hline \multirow[t]{2}{*}{ Mean } & 85.88 & & & 96.42 & & & 373.30 & & \\
\hline & \multicolumn{3}{|c|}{ number of kernels/spike } & \multicolumn{3}{|c|}{ 1000-kernel weight, g } & \multicolumn{3}{|c|}{ grain yield (Ard/fed) } \\
\hline Genotype & Mean & bi & $S^{2} d i$ & Mean & bi & $S^{2}$ di & Mean & bi & $S^{2}$ di \\
\hline Sohag 4 & 55.89 & 1.10 & 0.88 & 52.33 & 1.12 & $1.09 *$ & 20.67 & $1.14^{*}$ & -0.12 \\
\hline Sohag 5 & 53.39 & 0.80 & 0.16 & 51.32 & 0.90 & 0.55 & 21.33 & 1.08 & -0.14 \\
\hline Bani Suef 5 & 48.86 & 1.15 & $16.69 * *$ & 52.57 & 0.87 & -0.32 & 18.83 & $0.86^{*}$ & -0.03 \\
\hline Line1 & 53.83 & $0.49 *$ & $11.52 * *$ & 54.25 & 1.17 & -0.52 & 19.15 & $1.15^{*}$ & $0.42 *$ \\
\hline Line2 & 52.42 & 1.15 & $2.21 *$ & 51.07 & $0.77^{*}$ & -0.29 & 18.39 & 1.01 & 0.22 \\
\hline Line3 & 51.94 & 1.28 & 1.23 & 50.23 & 1.02 & 0.34 & 19.13 & 0.93 & -0.27 \\
\hline Line4 & 49.27 & $0.44 * *$ & -0.15 & 54.59 & 1.06 & 0.15 & 20.14 & 0.92 & -0.03 \\
\hline Line 5 & 48.70 & $1.56^{* *}$ & 1.09 & 51.04 & 1.06 & 0.31 & 19.04 & 0.89 & 0.17 \\
\hline Mean & 51.79 & & & 52.18 & & & 19.58 & & \\
\hline
\end{tabular}

Additionally, three genotypes (Bani Suef 5, line 1 and line 4) were the most desired genotypes for 1000-kernel weight and showed high mean performance when compared with grand mean beside their stability. These results are in harmony with those obtained by Amin (2006), Hamam and Abdel-Sabour (2009), Mohamed and Said (2014).

\section{Grain yield (ard/fed):}

In consideration to the stability parameters bi and $S^{2}$ di, out of the eight genotypes, five genotypes were stable over all the studied environments; i.e. their bi and $S^{2}$ di were insignificant. The other genotypes were unstable (bi was significant from unity and /or $\mathrm{S}^{2}$ di was significant from zero). More than only two out of five genotypes had grain yield above the grand mean. According to ascending orders of yields to these genotypes were Sohag 5 (21.33 ard/fed) and line 4 (20.14 ard/fed). It could be noticed that Bani Suef 5, line 3, line 4 and line 5 were considered specifically adapted to stressed environments $(\mathrm{bi}<1)$, while Sohag 5 and line 2 performed consistently better in favorable environments $(\mathrm{bi}>1)$. However, Line 1 gave reasonable mean yield but had high value of bi and $\mathrm{S}^{2}$ di than the remaining genotypes, which makes its performance unpredictable under varying environments and thus it is less stable. Sohag 4 produced mean yield (20.67 ard/fed) more average yield but had high value of bi (1.14) indicating specific adaptation particularly in high yielding environments. The most desired and stable genotypes can be considered when their regression coefficient equal one $(\mathrm{bi}=1)$ with lower values of $\mathrm{S}^{2} \mathrm{di}$ (Eberhart and Russell, 1966), accordingly in this study both genotypes Sohag 5 and Line 4 were considered as desired and stable for grain yield when compared with grand mean. These results are in line with those obtained by Amin (2006), Hamam and Abdel-Sabour (2009), Hassan et al. (2013), Abd El-Shafi et al. (2014) and Mohamed and Said (2014).

\section{REFERENCES}

Abd EL-Hameed, L.M. (2012). Response of four new bread wheat (Triticum aestivum L.) cultivars to nitrogen fertilizer levels under sprinkler irrigation system in sandy soil. Egyptian J. Agric., 34(1): 117.

Abd El-Shafi, M. A., Gheith E. M. S., Abd El-Mohsen A. A., and Suleiman H. S. (2014). Stability Analysis and Correlations among Different Stability Parameters for Grain Yield in Bread Wheat. Egypt. J. Plant Breed., 18(1): 83-93.

Abdel Nour, Nadya A. R., and Hayam S. A. Fateh. (2011). Influence of sowing date and nitrogen fertilization on yield and its components in some bread wheat genotypes. Egypt. J. Agric. Res., 89 (4): 1413-1433. 
Ahmed, Seham, M. M., Galil A. A., Basha H. A., and Mowafy A. A. E. (2009). Response of wheat to fertilization under sandy soil conditions. J. Agric. Res., 36: 1045-1067.

Akçura, M., Kaya Y., and Taner S. (2009). Evaluation of durum wheat genotypes using parametric and nonparametric stability statistics. Turkish J. Field Crops, 14(2): 111-122.

Ali, N., Javidfar F., and Mirza Y. (2003). Selection of stable rapeseed (Brassica napus L.) genotypes through regression analysis. Pak. J. Bot., 35: 175180.

Alisial, M., Arain M.A., Dahot M.U., Markhand G.S., Laghari K.A., Mangrio S.M., Mirbahar A.A. and Naqvi M.H. (2010). Effect of sowing dates on yield and yield components on mutant - cum Hybrid Lines of bread wheat. Pak. J. Bot., 42(1): 269-277.

Amin, I.A. (2006). Mean performance and stability analysis of some bread wheat genotypes under stress environments. The first Field Crops Conf. Aug., Giza, Egypt. 232-243.

Ansar, M., Cheema N. M., and Leitch M. H. (2010). Effect of agronomic practices on the development of septoria leaf blotch and its subsequent effect on growth and yield components of wheat. Pak. J. Bot., 43(3): 2125-2138.

Ashraf, M., Qureshi A.S., Ghafoor A. and Niaz A. K. (2001). Genotype-Environment interaction in wheat. Asian J. Biol. Sci., 1: 356-7.

Bartlett, M. S. (1937). Properties of sufficiency and statistical tests. Proc. Roy., Soc. London. Series A, 160: 268-282.

Cruz, C. D. (2013). Genes: a software package for analysis in experimental statistics and quantitative genetics. Acta Sci.. Agron., 35(3): 271-276.

Eberhart, S.A. and Russell W.A. (1966). Stability parameters for comparing varieties. Crop. Sci., 6(1): $36-40$

El Ameen, T. (2012). Stability analysis of selected wheat genotypes under different environment conditions in upper Egypt. African J. Agric. Res., 7(34): 4838-4844.

EI-Morshidy, M.A., Elorong E.E.M., Tammam A.M. and Abd EI-Gawad Y.G. (2000) Analysis of genotype $\mathrm{X}$ environment interaction and assessment of stability parameters of grain yield and its components of some wheat genotypes (Triticum aestivum L.) under new valley conditions. The $2^{\text {nd }}$ Scientific Conf. of Agri. Sci., Oct., Assiut, 13-34.

Fadle, A.A.H., El-Bana A.Y.A. , Omar A.E.A. and Abdul Hamid M.E.I. (2016). Response of some wheat cultivars to varying sowing dates and nitrogen fertilizer levels under sandy soil conditions. Zagazig J. Agric. Res., 43 (1): 29-48.
Gheith, E. M. S., El-Badry O. Z., and Wahid S. A. (2013). Sowing dates and nitrogen fertilizer levels effect on grain yield and its components of different wheat genotypes. Res. J. Agric. and Biol. Sci., 9(5):176-181.

Gomez, K. A., and Gomez A. A. (1984). Statistical Procedures for Agricultural Research. John Wiley \& Sons Inc. New York, USA.

Guenis A., Alpaslan M., Unal A. (2003). Effects of boron fertilization on the yield and some yield components of bread and durum wheat. Turk. J. Agric., 27: 329-335.

Guilioni, L., Wéry J. and Lecoeur J.(2003). High temperature and water deficit may reduce seed number in field pea purely by decreasing plant growth rate. Funct. Plant Biol., 30: 1151-1164.

Haddad, L., Bouzerzour H., Benmahammed A., Zerargui H., Hannachi A., Bachir A., Sami M., Oulmi A., Fellahi Z., Noura H. and Laala, Z. (2016). Analysis of Genotype x Environment Interaction for Grain Yield in Early and Late Sowing Date on Durum Wheat (Triticum durum Desf.) Genotypes. Jordan J, Biol. Sci., 9(3): 139146.

Hamam, K. A., and Abel-Sabour G. A. K. (2009). Stability of wheat genotypes under different environments and their evaluation under sowing dates and nitrogen fertilizer levels. Aust. J. Basic. and Appl. Sci., 3(1): 206-217.

Hameed, E., Shah W. A., Shad A.A., Bakht J. and Muhammad T. (2003). Effect of different planting dates, seed rates and nitrogen levels on wheat. Asian J. Plant Sci. 2 (6): 464-474.

Hassan, M. S., Mohamed G. I. A., and El-Said R. A. R. (2013). Stability analysis for grain yield and its components of some durum wheat genotypes (Triticum durum L.) Under Different Environments. Asian J. Crop Sci., 5(2): 179.-189.

Ismail, A.A. (1995). The performance and stability of some wheat genotypes under different environments. Assiut J. Agric. Sci., 26: 15.37.

Javaid Iqbal, Khizer Hayat and Safdar Hussain (2012). Effect of sowing dates and nitrogen levels on yield and yield components of wheat (Triticum aestivum L.). Pakistan J. of Nutri., 11(7): 531536.

Joppa, L R, Lebsock, K L, and Busch R H. (1971). Yield stability of selected spring wheat cultivars (Triticum aestivum L.) in the uniform regional nurseries, 1959 to 1968. Crop Sci., 11(2): 238241.

Kheiralla, K.A. and Ismail A.A. (1995). Stability analysis for grain yield and some traits related to drought resistance in spring wheat. Assiut J. Agric. Sci. 26, 253- 266. 
Kheiralla, K.A., EI-Morshidy M.A., Motawea M.H. and Saeid A.A. (2004). Performance and stability of some wheat genotypes under normal and water stress conditions. Assiut J. Agric. Sci. 35 (2): 7494.

Kiss, T., Balla K., Bányai J., Veisz O., and Karsai I. (2013). Effect of different sowing times on the plant developmental parameters of wheat (Triticum aestivum L.). Cereal Res. Communic., 42(2): 239-251.

Kouzegaran, M. R., Moosavi S. G., and Seghatoleslami M. J (2015). Effect of irrigation and nitrogen levels on yield and some traits of barley. Biol. Forum J. 7(1): 470-476.

Menshawy, A.M.M.(2007). Evaluation of some early bread wheat genotypes under different sowing dates:1. Earliness character. Fifth Plant Breeding Conference (May). Egypt J. Plant Breed., 11(1): 25-40.

Mohamed, N. E. M. and Said A. A. (2014). Stability parameters for comparing bread wheat genotypes under combined heat and drought stress. Egypt J Agron, 36(36): 123-146.
Nasim, G., Ashraf S., and Javaid A. (2006). Effect of sowing time on mycorrhizal development in wheat. Mycopath, 4(1): 13-19.

Parveen, L., Khalil I. H. and Khalil S. K. (2010). Stability parameters for tillers, grain weight and yield of wheat cultivars in North-West of Pakistan. Pak. J. Bot, 42(3): 1613-1617.

Prasad, P. V. V., Pisipati S. R., Ristic Z., Bukovnik U., and Fritz A. K. (2008). Impact of nighttime temperature on physiology and growth of spring wheat. Crop Sci., 48(6): 2372-2380.

Silva, P. R. D., Bisognin D. A., Locatelli A. B., and Storck L. (2014). Adaptability and stability of corn hybrids grown for high grain yield. Acta Sci.. Agron., 36(2):175-181.

Tammam, A.M. and Tawfelis M.B. (2004). Effect of sowing date and nitrogen fertilizer levels in relation to yield and yield components of durum wheat (Triticum turgidum var,durum) under upper Egypt environments. J. Agric. Sci. Mansoura Univ., 29(10): 5431-5442.

Tawfelis, M.B. (2006). Stability parameters of some bread wheat genotypes (Triticum aestivum L.) in new and old lands under Upper Egypt. Egypt J. plant breed., 10(1): 223-246. 


\section{الملخص المري}

\section{أداء وثبل بهض التركيب الورالثية من قمح اليورم تحت مواعيد زراعة وضستوبت تنميد نيتروجيف مختافة \\ أليمن جمل عبدالرالض، يلسرسسي إبرلهيم قبيصى \\ قم بحوث القمح - معرد بحوث المحاصل العقلية -مركز البحوث الزراعية}

لجريت هذه الدرلسة بمهة البحوث الزراعية بشندويل - مركز البحوث الزراعية - مصر. لقفيم ثمانية ترلكيب

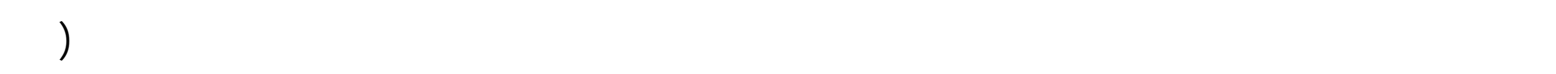

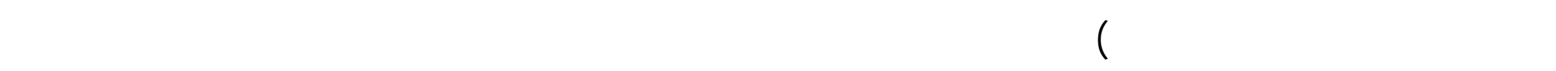

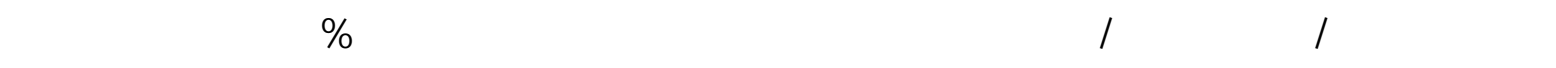

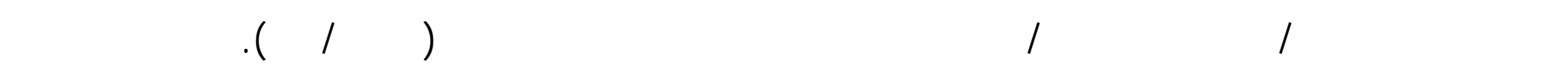

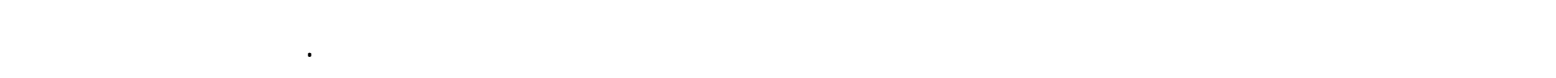

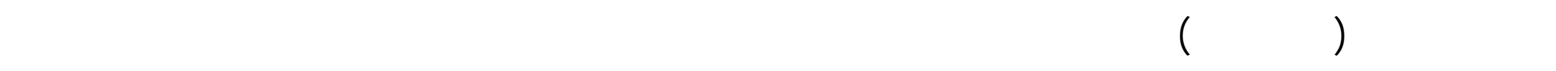

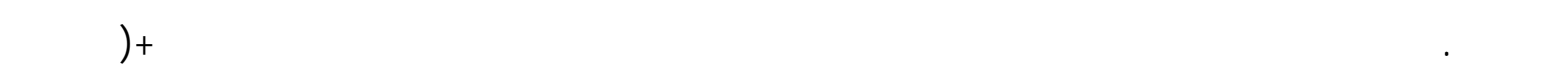

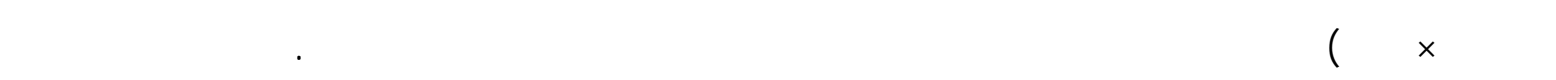

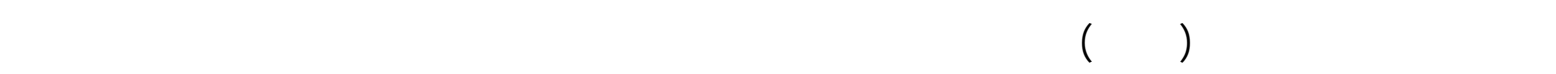

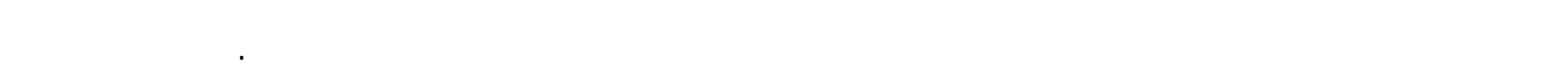

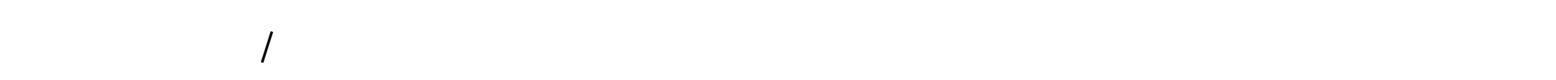

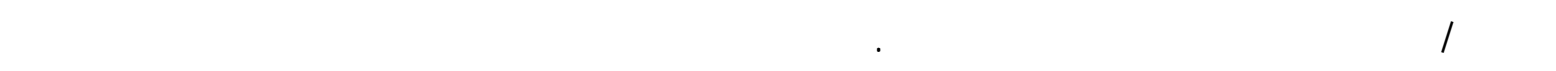

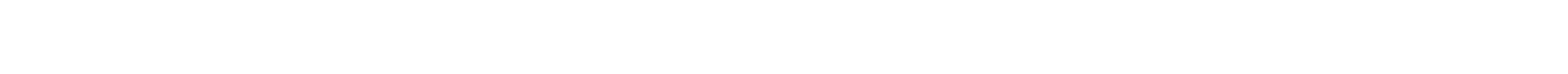

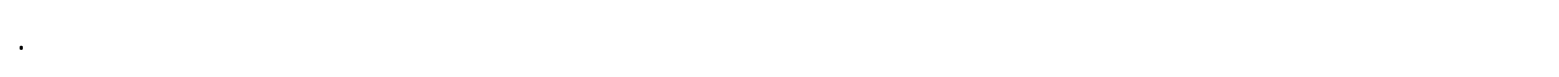
أعطت الثنين من هذه الترلكيبلسوهاج 0،سلالة رقم ع) محصول حبوب أعلى من المتوطط العلم للسلالات وبالتالي

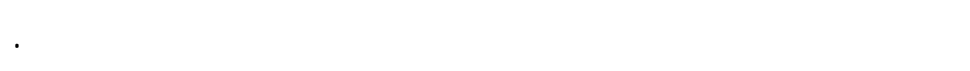

